\title{
Decoloniality of school governance in Lesotho: A Religio-historical approach
}

\author{
Rev. Dr. Rasebate Isaac Mokotso (Research Fellow) \\ Department of Language \& Social Education, National University of Lesotho \\ Department of Religion Studies, University of the Free State \\ ORCID ID: https://orcid.org/0000-0003-1293-5375 \\ rasebatemokotso@gmail.com \\ Doi: https://doi.org/10.46222/pharosjot.1035
}

\begin{abstract}
In this work, I examined the church's continuous ownership and governance of schools in Lesotho using colonial discourse analysis. I began by underlining the power struggle between the church and the state in school management, which dates back to the introduction of Western formal education in Lesotho by missionaries. I then argued that coloniality is the cause of the church's continued ownership and governance of schools. I also demonstrated how the church's continued ownership and administration of schools has harmed the church's credibility while also jeopardising education service delivery in the country. Decoloniality is presented as a counter-approach in my recommendation. Decoloniality deconstructs and reveals the limitations of coloniality ideology masquerading as the truth of events, as promoted by both religious and secular fundamentalists. Decoloniality proposes border thinking at various stages of delinking from a mission Christian education system. Border thinking assumes a diversity of viewpoints, with religious and secular viewpoints coexisting in the delivery of public education.
\end{abstract}

Keywords: Christianity, church schools, coloniality, decoloniality, fundamentalism, missionary education, public schools

\section{Introduction}

In this article, I discussed three points that stem from the church's continuing control over the schools. First of all, I believe that the continued control of schools by the church is the result of coloniality, the deepest level of colonialism. This argument evolved from coloniality paradigm that served as the framework for this article. Second, I believe the church's continued control of schools is not without its influence. It affects the general education services provided by the government. It further tarnishes the reputation of the church, as it continues to face criticism from secular groups. Finally, decoloniality is proposed as a counterplan to guide the church to reconsider its role in schooling education system. To address these points, three questions are pertinent; a) Why does the church continue to maintain its control over schools in Lesotho? b) What are the repercussions of the continued church control of schools? c) What can be done to guide the church to reconsider its role in school education?

Consistent with these thematic questions and the underlying coloniality framework, colonial discourse analytical method was used. Colonial discourse analytic method as defined by Burney (2012:175) is a critique of the discourse of cultural imperialism and colonial hegemony. It is used widely in different postcolonial theories including postcolonialism, neocolonialism and coloniality. Colonial discourse in consistent with Ashcroft, Griffiths and Tiffin (2007) represents a system that describes the relationship between the coloniser and the colonised. It has something to do with knowledge system, the belief system and the conditions of the colonial world. Although it is generated from the colonisers' worldview, it becomes the 
discourse that the colonised people turned to observe, perceive and define their existence. In this article, colonial discourse is employed to analyse the assumption that the church's continued control of public schools is a result of coloniality. Colonial discourse is employed to uncover 'colonial mentality,' which is defined by Decena (2014) as a state in which the postcolonised continue to cherish the attitudes, beliefs, and behaviours imposed by their colonisers.

\section{Background information}

The church owns and controls more than $90 \%$ of schools in Lesotho (World Education Data 2006). The term "church" is used in this article to refer to Christian institutions of various denominations. The church's dominance in Lesotho's education system can be traced back to the arrival of the Paris Missionary Society (PEMS) in the 1830s. According to Thelejani (1990), Molelle (2006), and Khalanyane (2011), the missionaries established a formal schooling system upon their arrival, with the goal of spreading the gospel and promoting Bible literacy and Christian doctrinal literacy. After the arrival of the Roman Catholic Church in the 1860s and the Anglican Church in the late 1870s, missionary education expanded even further Gill: 2010).

In 1869, Lesotho became a British colony. The church continues to have sway over the educational system. Rather than taking over the management and supply of education services, the colonial government aided the church through a grant-in-aid program (Mosisidi, 1981; Thelejani, 1990; Khalanyane, 2011). After independence in 1966, the influence of the church in the field of education had continued to increase. The church's involvement in education was reinforced by the then-Minister of Education and Culture, who stated that the Lesotho government had opted to continue to offer the church substantial authority in the provision of education services, and that such an arrangement was unlikely to end anytime soon. Indeed, the church's hold over the school is unlikely to be lifted anytime soon (Minister of Education and Culture, 1975).

Although the government appeared to back the church's ownership of schools beginning with the colonial administration, the power struggle between the two continued to develop. Khalanyane (2011) highlighted the events of power struggle during the colonial rule, which were manifested through the establishment of investigative commissions in the education system managed by the church. In 1905, the colonial government appointed a commission to investigate the education of the church. The commission issued its findings and recommendations in 1906. According to Sibisi (1962), one notable recommendation was to establish the Ministry of Education, which would be accountable for the school's pedagogical direction as well as the utilization of public funds. However, as Khalanyane (2011) indicates, the main body of the department was the Central Advisory Committee, which was composed of five members: the Government Secretary, Director of Education and three representatives of the Paris Evangelical Missionary Society, the Roman Catholic Church and the Anglican Church (called schools secretariats). Through the influence of church representation, the Central Advisory Committee decided to obstruct the implementation of the committee's recommendations. Another notable commission was formed in 1925, according to Matooane (1983), to examine the legitimacy of church-provided education. Following an investigation, it was suggested that the state enhance and monitor education more thoroughly, as well as making specific educational changes. The church approved other improvements, such as a standardized curriculum, the establishment of a national testing institution, and teaching standards, but not the control of the schools (Matooane, 1983).

Lesotho gained independence in 1966. The first step for the education department was to pass the education legislature called "Education Order No. 32." The main objective of the Education Act was to give the government full ownership and control of schools (Ministry of Education and Culture, 1971). Due to church dissatisfaction, the ordinance eventually gave the government the responsibility for other educational matters, rather than full control and 
ownership of the schools (Khalanyane, 2011). In 1975, the National Teacher Training College, a public teacher training institution, was established to replace the existing denominational teacher training colleges. This was not, however, without dispute. The government eventually gave in and allowed church denominations to have representatives at college in the form of teacher educators who prepare teachers to teach the Bible and Christian religion in the classroom (Khalanyane, 2011). According to Matooane (1983), a major post-independence commission was constituted in 1976 to examine the prospect of transferring school ownership from the church to the government. The commission reported at meetings of various stakeholders in the education field, including churches, parents, teachers, chiefs, parliamentarians, and government officials. In its report, the committee recommended that the government take over the management of the schools and nationalise the education system. The church representative left the meeting and immediately issued a statement saying that the church is the only institution obligated to provide educational services to Basotho society (Matooane, 1983).

Despite the commission's recommendations, possibly due to political reasons, the then Prime Minister issued a contradictory statement. It read thus, "It is the government's policy that church authorities should continue to play an important part in the running and development of education in Lesotho, especially because we are grateful for the religious foundations which they founded our education system" (Ministry of Education and Culture, 1978:82). In 1995, the government attempted to reduce the church's monopoly and strengthen cooperate schools management. There was an introduction of School Governing Bodies (SGBs) through a parliamentary Education Act Nō. 10 of 1995. The act defines Lesotho's education system as a 'three-legged' pot, that is, collaboration between the government, the church and the community (Ministry of Education and Training, 1995). Nonetheless, the Act maintained to describe the church as the school proprietor - that is, the owner of schools, according to Matalasi (2000). The church continued to hold major managerial roles during the founding of the SGBs. Minor adjustments were made through the passing of the Education Act Nō. 3 of 2010. The Act described church schools as "public schools" under church control (Ministry of Education and Training, 2010).

This backdrop is intended to demonstrate that Lesotho's education system has seen a power struggle in school governance between the church and the state since colonial rule. This kind of conflict, I feel, can only be described through a study of colonialism. I believe that the protracted conflict has harmed Lesotho's overall education supply and tarnished the church's terrible reputation.

\section{Coloniality framework}

In this article, I argue that colonialism is to blame for the church's uncompromising attitude on schools governance. Bulhan (2015:140-141) employs coloniality as a conceptual framework to correct the distortions of colonialism. Colonialism is misunderstood in various ways. First, it is often mistakenly restricted to a certain historical era, when Africa and other territories were subjected to European invasion, military control, and exploitation. In this sense, colonialism is defined solely in terms of politics and economics. This perspective dismisses the colonised thinking, behaviour, and the general life affected by overt cultural and psychological manipulations. Second, colonialism was misunderstood as obsolete, outmoded, and invalid once Africa gained political independence. Despite the fact that local agents, gofers, and conveyors continue to sustain colonialism today, colonialism is misunderstood as a system in which the colonized serviced people of European heritage (Bulhan, 2015:140-141).

Coloniality corrects this distortion. It explains colonialism's persistence beyond the control of one territory by another. Coloniality, according to Blanco (2019:602), refers to the long-term creation of a colonial power model, which includes hegemony, imperialism, and cognitive injustice. Coloniality, according to Mignolo (2007:159), is a power system that has far-reaching effects beyond the economic and political spheres of colonisation, such as race and 
geography divisions and economic usurpation. It takes the form of abstract things, such as Christian hegemony and cultural genocide, which are all taken for granted. Christian hegemony, according to Maldonado-Torres (2020), reflects the fundamental role in understanding colonialism. Christianity hegemony emerged in a colonial context as the belief that drew the line between communities with religion - Christian colonisers and nonreligious the colonised. The feature of being religious connects to the existence of a soul and without religion relates to the notion of being without a soul. For Maldonado-Torres (2020), Christianity was therefore a religion that distinguished between absolute human beings and those whose humanity was questioned. Such division warranted dissimilarities between those in the habitable zones and others who were considered in uninhabitable zones destined for the processes of Christianisation and civilisation. That is, domestication into human values and ideals.

Western missionaries fulfilled the colonial agenda of Christianisation and civilisation in Africa. In order to achieve their goal, they carefully presented education as a means to an end. According to Seroto (2018:2), missionary education had two objectives: one was to convert to Christianity and the other was to colonise the consciousness and ideas of the local population. Iskarna (2018:186) argues that, through the school system and church teaching, missionaries instructed Africans to recognise their pagan status as suitable for Christian conversion. Ezeanya-Esiobu (2019) supports that the task of the Western missionary was in the first place to Christianise local people and then westernisation of them. They accomplished this mission through socialisation and acculturation packaged and administered to the locals in the form of the gospel and the education system. Missionary education as described by Iskarna (2018:186), used Christianity to define non-Europeans as primitive, irrational, and exotic pagans, opposed to civilised, rational, and modern believers, thereby forcing Africans to submit to Western dominance and control. Christianity, therefore, was used as an ideological tool to enforce a myth, opinion or doctrine to induce the colonised into succumbing to colonial power and control.

Coloniality theory provides workable analytic framework. In terms of time and location, coloniality differs from colonialism. It does not necessarily begin with formal invasion of colonies by the colonists and ends with independence, that is, when external and direct administrative rule came to an end. Rather, it analyses the power dynamics that existed before settler, political, and economic colonialism and continue to this day. This was especially essential in determining the role of missionaries in the current controversy over school ownership because they were the first to be in charge of formal education in Lesotho. As it is not limited to political colonisation, coloniality aided in the examination of other types of colonial power or colonial logic, such as colonial mind-set, which continues to define social connections even after independence.

\section{Coloniality in the Lesotho's context}

In Lesotho, missionary education has traditionally emphasized Christian authority and control, according to Gill (2010). In a secular society, missionaries used their ostensibly better education to gain political and material advantage. They provided education that was trapped in the Christian ideology of western 'civilisation' or 'modernisation.' The first Basotho to receive mission education were the children of Christian converts. Their parents lived near the mission stations at first, but were eventually integrated into communities in order to 'leaven' the heathens (Gill 2010). E.S. Rolland, a missionary and government agent, wrote a colonial report on the political and social situation of the Basuto [Basotho] people, which praised missionary Christianity and education (Machobane \& Manyeli, 2001:184). The report revealed the extent to which Christianity and education contributed to the Basotho's cultural genocide. Basotho were socialised to undermine local political systems, acclimate to the western economic system, and disregard their cultural orientation as a result of mission religion and education. According to Rolland: 
When all this accomplished (process of acculturation) it will be easy to counteract, if all together to do away with, the power which then remain to the chiefs and headmen...The power of the native chiefs being supported by heathenism, and the chief being interested in the maintenance of heathen customs, whatever strikes at heathenism will proportionally weaken the chiefs. Educational and Christian institutions should therefore be encouraged (Machobane \& Manyeli, 2001:184).

The fruits of Christianity and mission education surfaced at the beginning of the twentieth century with the emergence of mission-educated aristocracy. The Basotho who graduated from mission schools acquired different identifications in literature like "petite bourgeoisie", "middling class", "modernized elites", "educated elite", "stooges of colonialism" and locally referred to as bahlalefi (the wise ones) or matsoelopele (the progressed or the civilised ones) (Epprecht, 1992; Eldredge, 2007; Gill, 2010). According to Epprecht (1992), this group described a vast range of professions and vocations, including teachers, clerks, "progressive farmers," evangelists, artisans, traders, and waged employees. Acted upon by Christian teaching and colonial ideals alike, these groups of people took up the outward attributes of 'tsoelopele' (civilisation). These include Western clothing and housing, English language, Christian marriage and nuclear family system.

The matsoelopele represented the first group in Lesotho to organise a political arm in 1907, the Basutoland Progressive Association (BPA) - 'Kopano ea Tsoelopele' in Sesotho, literally meaning 'the coming together of the civilised.' According to Epprecht (1992), their agitations were motivated by missionary propaganda. They foresaw changes in traditional politics, the economy, religion, and culture. They advocated for a move to private property and inheritable land ownership, as well as a reduction in chiefly power, the abolition of Sesotho customs, and participation in national decision-making. Rev Cranmer Sebeta, a Mosotho priest, was the BPA's president, confirming the organisation's Christian orientation (Gill 2010). Post-colonial government and post-missionary Christian leadership were to be passed on to the BPA. The BPA split into two groups as they moved closer to independence. The two represented the left wing (a faction campaigning for church leadership and political reforms) and the right wing (the group fighting for sustenance of the missionary and colonial status quo). According to Weisfelder (2002), the left wing represented Protestants, while the right wing represented Catholics.

These groups were mostly made up of teachers' unions, and they were, of course, in solidarity with other elite groups. According to Weisfelder (2002), the left wing attacked the following: 1) missionary education (particularly Catholic) that failed to meet the educational aspirations and interests of the nation; 2) expatriate school administrators; 3 ) the prevalence of expatriate brothers and sisters (Catholic celibates) in the teaching profession; 4) arbitrary dismissal of teachers; 4) missionary paternalistic style to school management; and 5) the dominance of denominational preferences in the appointment of teachers. The group advocated for the nationalisation of education under the sole direction of a single authority. It recommended that the Education Department be established under public jurisdiction, without the involvement of church officials (Weisfelder, 2002).

The other faction, according to Weisfelder (2002), allied with expatriate missionaries who demanded that schools be run by the church. They were opposed to the secularisation of education because they believed it would jeopardise the main purpose of church schools, which was to align with the Christian faith's ethos. They also contended that the church should be in charge of its schools. Secularising education was also seen as a challenge to colonial rulers that had developed favourable ties with the Catholic Church. Weisfelder (2002) goes on to show how the two wings eventually coalesced into the two major parties that brought Lesotho to independence. The BAC - Basutoland African Congress, which eventually became the BCP - Basutoland Congress Party - was clearly backed by the left side. CDP - Christian Democratic Party - and later BNP - Basotho National Party - were supported by the 
conservative right wing. In 1966, the right wing, greatly influenced by Catholic ideology but not publicly expressed in its platform, established Lesotho's first democratic government. It was in favour of "principles of social life and government based on the Gospel and on the Pope's encyclical letters" (Weisfelder, 2002:26).

This illustration supports the propositions of coloniality theory. Missionary imperialism, which exploited Christianity and education for power, control, and paternalism, is still alive and well in the church. The church's continuous control of schools is reminiscent of the missionary concept of education, which was based on Christianity and not viewed as a public enterprise. It also resembles the left wing of the BPA. The protestant and catholic divisions no longer exist in modern Lesotho, since the church functions in concord under the Christian Council of Lesotho (CCL). As a result, there are no longer right and left wings and decisions are made unanimously.

\section{Repercussions of the Church's persistence on schools' control}

Despite the fact that the church used its authority to the point that the situation was considered as normal, its control over schools has been criticized. Its insistence on maintaining control over schools tarnishes its reputation and integrity. Education is, after all, a public enterprise that is critical to the country's development goals. Though the church's role in public education has been idealised in recent years as a partnership in education, there is still much to be desired. According to a research by World Data on Education (2007), this cooperation has suffered from a lack of clarity in terms of obligations and responsibility for many years. The government appears to be responsible for all school-related costs, while the church appears to be the sole owner. Despite the government's recent increase in its share of education control, Ntho (2013) maintains that much more is needed for effective governance, management, and monitoring of public education delivery services. This situation is a problem for the country, which is responsible for ensuring equitable access to education for all citizens and judicious use of public education resources.

Several complaints have been levelled about the church's role in education over the years, which the church has ignored. The church is said to have used the schools as a source of cash at one point. The proceeds from the schools were used to support church dependents, such as priests and other members of the church community (Khalanyane, 2011). At other times, the church is accused of hiring teachers based on their denominational allegiance rather than their credentials. Students are also admitted based on their religious affiliation rather than their academic achievements (Motaba, 1998). Furthermore, the church has been accused of providing three educational systems in one country: Catholic, Protestant, and Anglican, thereby promoting denominational divide through public service (Mosisidi, 1989).

In the light of Education Act No. 3 of 2010 , schools are to be controlled by a democratically chosen board that includes community councillors, chiefs, parents, and church representatives from various public sectors. The roles and responsibilities are clearly defined, leaving no possibility for the church to exercise sole authority. The term 'ownership,' on the other hand, appears to imply that the board is working on behalf of the church's as the owner of schools. The Church School Education Secretariat office, which is responsible for liaising amongst church officials on educational concerns, continues to exist at church schools. The combination of the two leaves a lot to be desired (Ministry of Education and Training, 2010).

Nkanda (2017) conducted a study on the church's impact on school governing bodies and discovered some alarming findings: 1) rather than the quality of education given in church schools, proprietors prioritise church rituals and ideals. Church activities, in most situations, interfere with the learning-teaching schedule. As a result, learners' performance is affected; 2) because the church prioritises church practices and doctrine over the school's general educational goals, staff recruitment and admission policies conform to compliance rather than qualifications; 3) most, if not all, principals in church schools are members of church groups. 
Through the offices of the school secretariat, principal, and chairman of the school board, the church wields considerable influence over school governance.

Furthermore, a school, according to Blumenfeld (2006:198), serves as an institutional mechanism of preserving and reproducing societal norms. In church schools, curriculum materials reflect Christian privilege and the marginalization of members of other faith communities and non-believers in schools (curricular hegemony). Christian heroes, holidays, traditions, accomplishments, and the value of European Christian heritage are the focus of both formal and extracurricular activities. This is referred to as the "monocultural" school by Nieto (1998). The school whose structures, policies, curricula, instructional materials, and even pedagogical practices (which include hegemonic discourses) predominantly reflect the prevailing Christian culture. Only a few, if any, points of view from Hindus, Muslims, people of other religions, and non-believers are offered and debated.

The key aspect is that the church's emphasis on school administration is not ignored. Why is the church so keen on compromising its image and purpose in favour of school administration, as well as the supply of education in the country? The current paper explored this subject, employing coloniality theory as the determining element. Only a few, if any, points of view from Hindus, Muslims, people of other religions, and non-believers are offered and debated.

\section{Recommendation of decoloniality}

If the assumption that the church's insistence on school governance constitutes coloniality, then decoloniality would be the solution. Decoloniality, according to Ndlovu-Gatsheni (2013:12), is an approach that unearths and brings forth those silenced interpretations of events. Decoloniality reveals the ideological constraints of colonialism, which are disguised as the facts of events. Ndlovu-Gatsheni $(2015: 487)$ suggests that decoloniality differs from anticolonialism of the twentieth century, which was fundamentally a colonial-bred elite's goal. Decoloniality, in particular, focuses on a half-completed decolonisation endeavour. The extent of decoloniality is also unbounded to a moment of overpowering direct colonialism, but it begins before, during, and beyond that period. It is concerned with the imperialist concept of the West's dominance over the other, which existed before outright colonialism, throughout its history, and into present times.

Decoloniality advocates for "delinking" and "border thinking" on a more tangible basis. Delinking, according to Knobloch (2020:5), entails the dismantling of the colonial dynamics of power in order to unearth historically silenced voices. It works in unison with a concept known as "decentering," which has three theoretical dimensions: a) urging a change away from Eurohegemonic historical persuasion by drawing the 'other' from the periphery into the centre. That is, at the very least, providing for the interchange of ideas, logical reasoning, and debate between the two; b) cultivating and listening to marginalised historical sources that shaped the current condition of affairs; c) providing a chance for critical critique of hegemonic narratives by bringing in multiplication of historical constructions of events.

Decoloniality connotes an unfinished decolonisation endeavour to the Christian church of Lesotho. Despite the fact that decolonisation elites (bahlalefi/matsoelopele) were successful in dismantling the expatriate missionary and political colonial rule, Western authority is still maintained. Decoloniality proposes schools for the public world, rather than schools as instruments of power and control. Decoloniality supports Christianity as a way to liberate people from colonial misconceptions, rather than symbolising the religious arm of internal colonialism.

Delinking refers to separating oneself from Christianity's missionary educational goals. It suggests that we move away from Euro-Christian hegemony and instead listen to representatives of the "other," who represent the "public." Wilson (2006:351) defines public as the "publicity" of a variety of viewpoints and the "worldliness" of common history. The critical 
goal of delinking is to denaturalise the colonial/missionary education's historical frames, which distort and conceal its own historical cultural hegemony. The church in Lesotho is advised to adopt "border thinking" as a response to the existing predicament produced by coloniality. Border thinking is a kind of thought that exists on the dividing line between Christian and secular fundamentalism. The legacy of missionary/colonial Christianity is Christian fundamentalism. Missionary Christianity was offered to the Basotho people as the religion that had all of the spiritual, cultural, political, and socio-economic solutions.

According to Haynes (1995), Christian fundamentalism arose as a reaction to the church's perception that its way of life was under attack. As a result, it was created with the goal of transforming society according to Christian principles. Religious fundamentalism, according to Conkle (1996:352), is an insulated and insular system of thought; it is insulated from competing claims of truth and inhabits an epistemic cosmos disconnected from other ways of reckoning. Fundamentalists often battle the government because they are afraid that the latter's jurisdiction will extend to areas that they believe are essential to the development of a proper society. These areas include education, employment policy (employment of people of all faiths), and the general moral attitude of society. Their religion is seen as the only credible source of accuracy on all problems, legitimising their control over the provision of public services.

While Christian elites in Lesotho represent Christian fundamentalists, there is a faction of bahlalefi - political elites preaching secularism - who advocate for the exclusion of the church in the public arena. Secularism, on the other hand, is accused of the same things as Christian extremists. Secularism encourages secular fundamentalists, as defined by Conkle (1996:352). Secular fundamentalism embraces political liberalism's values, rejecting religion as a source of public truth. As a result, in the public realm, only reason reigns supreme. Morality and ethics are also provided by secular rationalism, which is based on fairness, neutrality, and justice.

The underlying advice is that the church should avoid religious fanaticism and relinquish authority over public schools. The church's insistence on school control generates criticism from all levels of society, undermining its credibility. At the same time, the church must avoid becoming a victim of secularizing forces. This can be accomplished simply by adopting a broader thinking approach, one that does not overly advocate religion or secularism. The concept of the 'public' serves as a starting point for border thinking. To define "public," Giumbelli (2018:288-289) divides it into three dimensions: publicness - that which is of widespread concern or that which continues to be a problem for the public; publicity - that which violates privacy and becomes public; and publics - that which addresses the publics collectively. Wilson (2006:350) refers to "the space of appearance" as a summary of the three. When public actors (people) interact in both speech and action, the public sphere emerges. The presence of an individual within the space of others, to act and communicate, is referred to as public appearance. Everyone listens and is heard when it comes to public appearance. It is a zone where opposing viewpoints and behaviours coexist; publicity is synonymous with diversity or plurality.

\footnotetext{
Plurality is the basic human condition that corresponds to action, "because we are all the same that is, human, in such a way that nobody is ever the same as anyone else who ever lived, lives, or will live" ... Plurality, thus, is two-fold: we are the equal, "the same, that is human," and distinct, "in such a way that nobody is ever the same" ... equality does not mean "sameness," and distinct does not mean "otherness"... When we appear in the world, through speech and action, we are able to appear as "who" in distinction to "what" we are; we are most fully human (Wilson, 2006: 350).
}

Pluralism in border thinking requires a school, which Fabretti (2013:59) defines as a postsecular school. A postsecular school is one in which the state and religious communities 
share responsibilities for the delivery of education service. It's a school where educational issues are addressed through collaboration that meets the criteria of the mutual existence of various worldviews. It is the educational environment that suggests a reflexivity attempt by both religious and secular players. Pluralism, according to Fabretti (2013:59), encourages schools to acknowledge religious organizations' contributions to education by enabling them to reflect their own traditions and truth claims. Simultaneously, religious communities are encouraged to engage in democratic "fair play," eschewing all types of proselytise and religious prejudice. Religious involvement in school governance should follow democratic and network patterns that allow for the creation of institutional space based on reciprocal contribution. All public space actors, including the state, students, and the community, must claim a fair portion in the school's management. According to Colombo (2013:9), border thinking idealises the postsecular school as a normative model anchored by a new sort of desecularised school, a public place in which both secular and religious communities demand the right to public acknowledgement.

\section{Conclusions}

Coloniality lives on in less visible ways than the presence of colonists and the colonised socioeconomic and political subjection. It created a situation in which the colonised felt compelled to unintentionally protect the colony's legacies as their responsibility. The church's persistence on school governance is likely motivated by a desire to preserve the historic legacy of education supply, but it does so within the coloniality of power and hegemony. The church's persistent fixation on owning and administering schools may stem from the belief that it is its job to carry on where missionaries left off. Such belief prevents it from seeing the political and moral consequences. The practices that perpetuate colonialism can only be undone through radical awareness intervention, and the decoloniality reaction may constitute an exciting agenda for disturbing colonial persistence. Adopting a border thinking technique does not negate the church's involvement in education in any way. It does, however, propose a non-dominant approach that appreciates the contributions of other society sectors.

\section{References}

Blanco, R. (2019). Problematising the Ultimate Other of Modernity: the Crystallisation of Coloniality in International Politics', Contexto Internacional, 41(3), 599-619.

Blumenfeld, W. J. (2006). Christian Privilege and the Promotion of "Secular" and Not-So "Secular" Mainline Christianity in Public Schooling and in the Larger Society, Equity and Excellence in Education, 39, 195-210.

Bulhan, H. A. (2015). Stages of Colonialism in Africa: From Occupation of Land to Occupation of Being, Journal of Social and Political Psychology, 3(1), 239-256.

Colombo, M. (2013). Introduction. Pluralism in Education and Implications for Analysis, Italian Journal of Sociology of Education, 5(2),1-16.

Conkle, D. O. (1996). Secular Fundamentalism, Religious Fundamentalism, and the Search for Truth in Contemporary America, Journal of Law and Religion, XII(2), 337-370.

Eldredge, E. A. (2007). Power in Colonial Africa: Conflict and discourse in Lesotho, 18701960, The University of Wisconsin Press, London.

Epprecht, M. (1992). Women, Class and Politics in Colonial Lesotho, 1930-1965, PhD dessertation, Dalhousie University. 
Ezeanya-Esiobu, C. (2019). Indigenous Knowledge and Education in Africa, Springer, Los Angeles.

Fabretti, V. (2013). Learning from religions. Post-secular Schools and the Challenge of Pluralism, Italian Journal of Sociology of Education, 5(2), 46-66.

Gill, S. J. (2010). A Short History of Lesotho, Morija Museum and Archives, Morija.

Giumbelli, E. (2018). Public Spaces and Religion: An Idea to Debate, a Monument, Publicado em Horizontes Antropológicos, (51), 279-309.

Haynes, J. (1995). Religion, Fundamentalism and Ethnicity: A Global Perspective. UNRISD, Discussion Paper 65, The United Nations Research Institute for Social Development (UNRISD), Geneva, Switzerland.

Iskarna, T. (2018). The Relation between Christianity and Colonialism in Ngugi Wa Thiong'o's The River Between, Journal of Language and Literature, 18(2), 184-193.

Khalanyane, T. (2011). Power and Struggle: A Critique of Hegemony and Control of Schooling in Lesotho, Lambert Academic Publishing, Berlin.

Knobloch, P. D. (2020). Epistemological Decolonization and Education. International Perspectives, Foro de Educación, 18(1), 1-10.

Lewis, A. \& Steyn, J. C. (2003). A critique of mission education in South Africa according to Bosch's mission paradigm theory, South African Journal of Education, 23(2), 101-106.

Machobane, L. \& Manyeli, T. (2001). Essays on Religion and Culture Among Basotho, Mazenod Publishers: Mazenod.

Maldonado-Torres, N. (2020). Religious Studies and/in the Dicolonial Turn, Contending Modernities: Exploring how Religious and Secular Forces Interact in the Modern World, University of Notre Dame, [Available online at http://www. https://contendingmodernities.nd.edu] (Retrieved December 15, 2020).

Matalasi, J. (2000) The Role of the School Governing Bodies in Lesotho: A Case Study of Four High Schools, MED Dissertation, University of the Witwatersrand.

Matooane, L. J. (1983). A historical interpretation of Lesotho's educational system, Rutgers University, New Jersey.

Mignolo, W. D. (2007). Coloniality of power and de-colonial thinking, Cultural Studies, 21 (23), 155-167.

Ministry of Education and Culture. (1971). Education Order No. 32, Government Printing, Maseru.

Minister of Education and Culture. (1975). The Second Five-Year Development Plan 1975/6 1979/80, Government printing, Maseru.

Ministry of Education and Culture. (1978). The National Dialogue in Education, Government Printing, Maseru. 
Ministry of Education and Training. (1994). Education Act No 4 of 1994, Government Printing, Maseru.

Ministry of Education and Training. (2010). Education Act Nō 3 of 2010, Government Printing, Maseru.

Molelle, H. K. (2006) Global Policy Discourse and Local Implementation Dynamics: A Case Study of Lesotho's Junior Certificate Religious and Moral Education Syllabus. MED Dissertation, University of Cape Town. Unpublished MED

Mosisili, P. B. (1981). A Curriculum Development Process: The Lesotho Experience, MED Dissertation, Simon Fraser University.

Motaba, M. N. (1998). The Lesotho Education Act of 1995/96, and its Socio-Economic and Academic Impact on Teachers: A Case Study in Maseru, Lesotho, MED Dissertation, The University of the Witwatersrand.

Ndlovu-Gatsheni, S. J. (2015). Decoloniality as the Future of Africa, History Compass, 13(10), 485-496.

Ndlovu-Gatsheni, S. J. (2013). Why Decoloniality in the 21st Century?, The Thinker for Thought Leaders, 4(8), 10-15.

Nieto S. (1998). Cultural Difference and Educational Change in a Sociopolitical Context, in A. Hargreaves, A. Lieberman A, M.Fullan \& D. Hopkins (Eds), International Handbook of Educational Change, Dordrecht, Springer, 418-439.

Nkanda, N. D. (2017). The Influence of School Proprietors on the Roles and Responsibilities of School Governing Bodies in Church-owned Schools in Lesotho, MED Dissertation, University of South Africa.

Ntho, M. N. (2013). Lesotho: Effective Delivery of Public Education Services, Johannesburg, The Open Society Initiative for Southern Africa.

Seroto, J. (2018). Dynamics of Dicoloniality in South Africa: A Critique of the History of Swiss Mission Education for Indigenous People, Studia Historiae Ecclesiaticae, 44(3), 1-14.

Sibisi, R. C. (1962). Development of secondary education in Basutoland, MED thesis, University of South Africa.

Stoeckl, K. (2017). Political liberalism and religious claims: Four blind spots, Philosophy and Social Criticism, 43(1), 35-50.

Thelejani, T. S. (1990). Implementing Educational Policies in Lesotho. World Bank Discussion Papers: Africa Technical Department Series, Washington, D.C., The World Bank, United States of America, The International Bank for Reconstruction and Development/The World Bank.

Wiesfelder, R. F. (2002). Political Contentions in Lesotho, 1952-1965, Morija Printing Works, Morija.

Wilson, T. S. (2005). Schools as Public Spaces: The Tensions and Resources of Arendt, Philosophy of Education, 347-355. 
World Data on Education. (2006). Lesotho, viewed 12 December, from UNESCO: http://www.ibe.unesco.org (Retrieved October, 12, 2021). 